\title{
Challenges To Sustainable Supply Chain Management And Their Interrelation In The Apparel Sector Of Bangladesh: A Dematel Approach
}

Md. Rezaul Karim, MSc

Tunazzina Ahammed, BSc

Md. Sabbir Hossen, BSc

Nazmus Sakib, BS

S.M. Mohaimin, BSc

Bangladesh University of Textiles, Bangladesh

\section{Doi:10.19044/esj.2021.v17n15p409}

Submitted: 02 December 2020

Accepted: 27 April 2021

Published: 31 May 2021
Copyright 2021 Author(s)

Under Creative Commons BY-NC-ND

4.0 OPEN ACCESS

Cite As:

Karim R., Ahammed T., Hossen S., Sakib H. \& Mohaimin S.M. (2021). Challenges To Sustainable Supply Chain Management And Their Interrelation In The Apparel Sector Of Bangladesh: A Dematel Approach.

European Scientific Journal, ESJ, 17(15), 409. https://doi.org/10.19044/esj.2021.v17n15p409

\section{Abstract}

The apparel industry is the prime driving force of the Bangladesh economy, contributing 83\% to the total export earning with 27.94 billion USD in 2019-2020. The apparel industry has to deal with an intricate supply chain globally. While many apparel-exporting countries adopt sustainable supply chains, Bangladesh is still under the traditional supply chain umbrella. Sustainable supply chain in the apparel sector of Bangladesh is in the nascent stage yet. This study explores the challenges to the sustainable supply chain and their interrelation in the apparel sector of Bangladesh. This study incorporates thirty barriers in five categories (environmental, economic, societal, knowledge \& technology, and Management \& Stakeholders). This study is quantitative in nature, and data collection was completed two-fold. Two questionnaires were designed to garner a response. The first questionnaire was used to collect responses from experts (academic, buyinghouse, and industry people)to determine the most prominent barriers and shortened number of obstacles from thirty to eighteen. The second questionnaire was designed to collect responses from hundred respondents as input in the comparison matrix of DEMATEL. Finally, DEMATEL based 
method was applied to investigate the interrelation among the barriers. From the result of the study, according to prominence value, lack of stakeholder involvement, high costs of sustainability adoption, insignificant financial gains, lack of supply chain integration are the prime barriers to SSCM. Moreover, this study unravels the cause-effect relationship among the barriers, ten barriers fall in the cause group, and eight barriers fall in the effect group, and finally, proposed corrective action to address the cause barriers.

Keywords: DEMATEL, Sustainable Supply Chain Management, Interrelation Of Challenges, Bangladesh Apparel Sector

\section{Introduction}

Supply chain management is an integral part of businesses and is essential to company success and customer satisfaction. These practices help improve financial position, improve customer services, and reduce operating costs (Majumdar \& Sinha, 2019). Lesser known is the role of sustainable supply chain management in business and society. SSCM integrates both social and environmental dimensions with economic considerations, and it is still one of the newer concepts to be applied in companies (Moktadir et al., 2018). Moreover, if the textile and apparel industry is focused explicitly on, it becomes apparent that the rising level of outsourcing from developing countries has also increased the importance of sustainability. As the consumer lifestyle and demands keep changing, it puts pressure on the existing supply chain formats to modify and merge sustainability concepts in the upgraded system (Taghikhah et al., 2019). Thus, many well-known retailer brands have shifted from regular supply chain practices to SSCM. Sustainable supply chain management also creates additional advantages during the applied approach because it considers social, environmental, and economic factors (Gardas et al., 2018). The RMG sector in Bangladesh has become the economy's backbone as the largest export earnings source (84\% of the total export) and employment (4.5 million direct employment and 20 million indirect employment)(Bank, n.d.). However, at the current growth pace, the target is not possible to achieve.

Furthermore, the industry has witnessed the collapse of around 200 firms in recent times, which indicated the newly added factories are fully compliant and are here to stay (Coronavirus: Bangladesh's Garment Industry Risks Collapse | Asia| An in-Depth Look at News from across the Continent | $D W \mid 25.03 .2020$, n.d.). Therefore, though the number of new industries every year decreases, the freshly launched industries' quality is far better, taking Bangladesh to the next level as a role model of green initiatives and sustainable practices. Industry transformation phase, will propel a significant shift from regular supply chain systems into a sustainable supply chain. Both the textile 
and the apparel sector stand to gain vastly from this, as less information and more dependency on developing countries for resources was what prompted this shift globally in the first place.

In the apparel industry, traditional supply chain management needs to be upgraded into a sustainable one. In this regard, SSCM practices may help make the traditional supply chains more sustainable by considering the Triple Bottom Line (economic, social, and environmental) and considering knowledge and technology and management and stakeholder participation (Craig R. Carter \& Easton, 2011). Implementing SSCM practices in the Bangladeshi apparel industry will be challenging due to the numerous barriers that currently exist. In this sense, this research raises some questions:

a. What are the key barriers to implement SSCM practices in the apparel supply chain?

b. What are the contextual (cause-effect) relationship among barriers

c. How can managers interpret cause and effect relationships among selected barriers?

This study has set the below objectives:

a. To identify the critical barriers to the adoption of SSCM practices in the T\&A. industry of Bangladesh.

b. To understand the cause and effect relationships between selected barriers.

\section{Literature Review}

The term 'supply chain management' started evolving in the 1980s (Harland, 1996). In just a few years, this has emerged as a phenomenon of exceptional interest due to its applications in a wide array of domains. Several studies have explored the concepts of SCM and its importance in a variety of fields. Seuring \& Müller (2008) defined supply chain management as a set of tasks that ensure the flow of information, finance, and goods from suppliers to end-users . The supply chain ensures the flow of material, information, and capital through proper channels among firms considering all three sustainability wings. Lambert et al. (1998) defined SCM as integrating pivotal business activities from suppliers to the customer, which provide products, services, and information for the value addition to customer and stakeholders. Customer need satisfaction and effective logistics management drive the maximization of value creation among stakeholders and enterprise. Management of relationships among key stakeholders and enterprise functions is supply chain management (Walters \& Lancaster, 2000). A typical supply chain framework evolved, integrating environmental and social issues and economic concerns with the advancement of sustainable operations management (Seuring \& Müller, 2008). Supply chain management plays a pivotal role in today's business arena where sustainability has called for 
industrialist and researchers' attention from different aspects (Islam et al., 2020). Regardless of business organizations' size or nature, sustainability has become an inseparable part of their business (Kaur et al., 2018). Sustainability is the term that describes the capability to perform business with a vision of maintaining the society, environment, and economy (Hassini et al., 2012). Slawinski \& Bansal (2011) defined sustainability as creating flexible firms by aligning economic, social, and environmental systems without sacrificing long-term goals. Sustainability practices pose different challenges to decisionmakers, supply chain managers, and policymakers in the organization's supply chain (Marshall et al., 2015). Sustainable or green management initiatives have been launched to curtail cost and improve efficiency, customer satisfaction, market share, and sales. The acknowledgment of environmental impact due to efficient supply chain management led to the development of Green Supply Chain Management. GSCM focuses on the environment and economic aspects but fails to communicate social concerns, leading to unveiling Sustainable Supply Chain Management (Bansal \& Roth, 2000; Lintukangas et al., 2016).

Seuring \& Müller (2008) reported SSCM as an alignment of sustainable development and supply chain management, combining social and environmental concepts. SSCM is the extension of traditional supply chain management, merging all three-dimension (social, economic,and ecological) sustainability (Ciliberti et al., 2008; Font et al., 2008). Sticking to the traditional supply chain led to the downgrade of organizational performance. Hence, a sustainable supply chain shift is emphasized (Sarkis, 2012; Tseng et al., 2019). The concepts of sustainable development depend on the Triple Bottom Line (TBL) dimensions (economic, environmental, and social). The sustainability progression in the supply chain has also seen a notable contribution from two pillars: a combination of sustainability: socioeconomic, socio-environmental, and eco-environmental dimensions (Rajeev et al., 2017). Most of the articles between 2003-2018 shed light on all three dimensions of sustainability. Environmental and economic dimensions in combined or economic and social dimension jointly get focus in less article. Sustainability's social dimension solely received the most attention in the papers (Koberg \& Longoni, 2019). Carter \& Liane Easton (2011) and Svensson \& Wagner (2015) have indicated social, economic, and environmental as three wings of SSCM. Building up parity between profit, planet, and people in the clothing industry, it is substantial to address three sustainability pillars (Jabbour \& Santos, 2008; Khan et al., 2018; Pomponi et al., 2019). Implementation of social sustainability magnifies operational performance and organizations' financial success (Schönborn et al., 2019). Lack of environmental regulations is often regarded as critical challenges for SSCM adoption (Wittstruck \& Teuteberg, 2012), whereas rigid and expensive 
environmental policy may impede a company's environmental proactivity (EM \& C., 1995). Businesses with a target to reach minimal prerequisites may turn down the capacity to develop new technologies and solutions to boost environmental performance (Sajjad et al., 2015). Investment in SSCM needs to be mirrored by economic restoration; otherwise, organizations become unwilling to participate in SSCM practices without benefits (Sajjad et al., 2015). The observation of an uncertain economy stem from integrating SSCM practices may falter the organization's venture (Giunipero et al., 2012). (Mont et al., 2014) suggested stakeholder involvement as crucial to SSCM initiatives, while (Lorek \& Spangenberg, 2014) reported a sheer number of stakeholders, primarily from non-developed countries lacking knowledge about sustainability. Top management's commitment is critical to the initiation of SSCM, but disinterest from the top and mid-level management may shrink the organization's capability to facilitate SSCM initiatives (Wittstruck \& Teuteberg, 2012).

Table 1. Key challenges to SSCM

\begin{tabular}{|c|c|c|c|}
\hline Author & Challenges & Method & $\begin{array}{l}\text { Industry } \\
\text { (Country) }\end{array}$ \\
\hline $\begin{array}{l}\text { (Q. Zhu et al., } \\
\text { 2005) }\end{array}$ & $\begin{array}{c}\text { Absence of central government environmental } \\
\text { regulations, Lack of buying firms environmental } \\
\text { mission, }\end{array}$ & $\begin{array}{c}\text { Regression } \\
\text { analysis }\end{array}$ & $\begin{array}{l}\text { Manufacturing } \\
\text { (China) }\end{array}$ \\
\hline $\begin{array}{l}\text { (Walker et al., } \\
\text { 2008) }\end{array}$ & $\begin{array}{l}\text { High costs of sustainability adoption, fear of } \\
\text { exposure of poor environmental performance, lack } \\
\text { of information, inertia by project stakeholders, } \\
\text { supplier's (manufacturer) reluctance to change, } \\
\text { Disbelief about environmental benefits }\end{array}$ & $\begin{array}{l}\text { Exploratory } \\
\text { factor analysis }\end{array}$ & $\begin{array}{l}\text { Manufacturing } \\
\text { (The U.K.) }\end{array}$ \\
\hline $\begin{array}{c}\text { (Diabat \& } \\
\text { Govindan, 2011) }\end{array}$ & $\begin{array}{l}\text { Reverse logistics, a collaboration between product } \\
\text { designers and suppliers to reduce and eliminate } \\
\text { product environmental impacts }\end{array}$ & ISM & $\begin{array}{l}\text { Manufacturing } \\
\text { (India) }\end{array}$ \\
\hline $\begin{array}{c}\text { (Luthra et al., } \\
\text { 2011) }\end{array}$ & $\begin{array}{l}\text { Lack of top management commitment, } \\
\text { lack of information technology }\end{array}$ & ISM & $\begin{array}{c}\text { Automobile } \\
\text { (India) }\end{array}$ \\
\hline $\begin{array}{l}\text { (Kannan Govindan } \\
\text { et al., 2014) }\end{array}$ & $\begin{array}{l}\text { The Complexity of measuring/monitoring } \\
\text { environmental practices of suppliers, } \\
\text { Lack of corporate social responsibility }\end{array}$ & AHP & $\begin{array}{l}\text { Manufacturing } \\
\text { (India) }\end{array}$ \\
\hline $\begin{array}{l}\text { (Mathiyazhagan et } \\
\text { al., 2013) }\end{array}$ & $\begin{array}{l}\text { The problem in maintaining the environmental } \\
\text { awareness of suppliers, lack of top management } \\
\text { involvement, Complexity in measuring and } \\
\text { monitoring the environmental practice of suppliers }\end{array}$ & ISM & $\begin{array}{l}\text { Auto component } \\
\text { (India) }\end{array}$ \\
\hline $\begin{array}{l}\text { (Qinghua Zhu \& } \\
\text { Geng, 2013) }\end{array}$ & $\begin{array}{l}\text { Insignificant financial gains, lack of resource and } \\
\text { capability }\end{array}$ & $\begin{array}{c}\text { Exploratory } \\
\text { factor analysis }\end{array}$ & $\begin{array}{l}\text { Manufacturing } \\
\text { (China) }\end{array}$ \\
\hline $\begin{array}{l}\text { (Jalalifar et al., } \\
\text { 2013) }\end{array}$ & $\begin{array}{c}\text { Lack of top management support, lack of } \\
\text { information and data, lack of supply chain } \\
\text { integration }\end{array}$ & DEMATEL & $\begin{array}{l}\text { Manufacturing } \\
\text { (Iran) }\end{array}$ \\
\hline $\begin{array}{c}\text { (Luthra et al., } \\
\text { 2016) }\end{array}$ & $\begin{array}{c}\text { Lack of government support and policies, lack of } \\
\text { management support, lack of resource and expertise, } \\
\text { lack of stakeholders involvement }\end{array}$ & AHP & $\begin{array}{l}\text { Plastic } \\
\text { manufacturing } \\
\text { (India) }\end{array}$ \\
\hline
\end{tabular}




\begin{tabular}{|c|c|c|c|}
\hline (Wang et al., 2016) & $\begin{array}{c}\text { Lack of adequate training and progress monitoring, } \\
\text { low customer awareness, lack of pressure for } \\
\text { widespread adoption }\end{array}$ & DEMATEL & $\begin{array}{l}\text { Food packaging } \\
\text { (India) }\end{array}$ \\
\hline $\begin{array}{l}\text { (Gandhi et al., } \\
\text { 2015) }\end{array}$ & $\begin{array}{l}\text { Top management commitment, human } \\
\text { technical expertise, adoption of new technology and } \\
\text { processes }\end{array}$ & DEMATEL & $\begin{array}{l}\text { Manufacturing } \\
\text { (India) }\end{array}$ \\
\hline (Xia et al., 2015) & $\begin{array}{c}\text { Less profit in remanufacturing } \\
\text { Lack of cooperation with research institutes }\end{array}$ & DEMATEL & $\begin{array}{l}\text { Automotive } \\
\text { (China) }\end{array}$ \\
\hline $\begin{array}{l}\text { (K. Govindan et } \\
\text { al., 2015) }\end{array}$ & Customer pressure & Fuzzy AHP & $\begin{array}{l}\text { Manufacturing } \\
\text { (India) }\end{array}$ \\
\hline (Rao \& Holt, 2005) & Fear of failure & SEM & Southeast Asia \\
\hline $\begin{array}{l}\text { (Silvestre et al., } \\
\text { 2018) }\end{array}$ & Strong perception of low economic returns & $\begin{array}{l}\text { Theoretical } \\
\text { Framework }\end{array}$ & $\begin{array}{l}\text { Beef Industry } \\
\text { Brazil }\end{array}$ \\
\hline $\begin{array}{l}\text { (Moktadir et al., } \\
\text { 2018); Shibin et } \\
\text { al., 2018) } \\
\end{array}$ & $\begin{array}{c}\text { Ineffective supplier selection strategies } \\
\text { The inefficient performance measurement system } \\
\text { Ineffective employee training for sustainability }\end{array}$ & DEMATEL & $\begin{array}{l}\text { Leather Industry } \\
\text { (Bangladesh) }\end{array}$ \\
\hline $\begin{array}{l}\text { (Majumdar \& } \\
\text { Sinha, } \\
\text { 2019)(Koberg \& } \\
\text { Longoni, 2019) }\end{array}$ & $\begin{array}{l}\text { Lack of effective interdepartmental communication } \\
\text { Non-consideration of human factors }\end{array}$ & ISM & $\begin{array}{l}\text { Southeast Asia } \\
\text { Textile and } \\
\text { Apparel Industry }\end{array}$ \\
\hline $\begin{array}{l}\text { (Kannan Govindan } \\
\text { et al., 2014) }\end{array}$ & $\begin{array}{c}\text { High cost for disposing of hazardous wastes } \\
\text { Cost of environmentally friendly packaging } \\
\text { Non-availability of financial assistants } \\
\end{array}$ & ISM & $\begin{array}{l}\text { Auto component } \\
\text { (India) }\end{array}$ \\
\hline $\begin{array}{l}\text { (Prakash \& Barua, } \\
\text { 2015) }\end{array}$ & Demand for lower price & AHP-TOPSIS & \\
\hline $\begin{array}{c}\text { (Sarker et al., } \\
\text { 2018) }\end{array}$ & Market competition and uncertainty & $\begin{array}{l}\text { Delphi study } \\
\text { approach }\end{array}$ & $\begin{array}{l}\text { Leather Industry } \\
\text { (Bangladesh) }\end{array}$ \\
\hline $\begin{array}{l}\text { (Hasan, 2016) (Shi } \\
\text { et al., 2008) }\end{array}$ & Weak regulatory environment & AHP & $\begin{array}{l}\text { SME } \\
\text { China }\end{array}$ \\
\hline
\end{tabular}

A closer look at the literature reveals several gaps and shortcomings

a. Although a few attempts have been made to address these issues, it is still limited to a subset of the dimension of sustainability in supply chain management.

b. There are no previous literature reports that explored challenges to adopt SSCM in the T\&A of Bangladesh.

c. Previous research typically investigated the implementation of GSCM in various fields, taking into account environmental sustainability only.

d. Finally, it is pivotal to identify challenges from a cause-effect relationship perspective.

\section{Methodology}

Table 2. Category of key challenges in SSCM

\begin{tabular}{|l|l|l|l|}
\hline SL No. & Challenges Type & Challenges Name & Code \\
\hline B1 & \multirow{4}{*}{ Economical } & High costs of sustainability adoption & EC1 \\
\cline { 3 - 4 } B2 & & Insignificant financial gains, & EC2 \\
\cline { 3 - 4 } & & Lack of resource and capability & EC3 \\
\hline B3
\end{tabular}




\begin{tabular}{|c|c|c|c|c|}
\hline B4 & & & High cost for disposing of hazardous wastes & EC4 \\
\hline B5 & & & Cost of environmentally friendly packaging & EC5 \\
\hline B6 & & & Non-availability of financial assistants & EC6 \\
\hline B7 & \multirow{5}{*}{\multicolumn{2}{|c|}{ Environmental }} & Lack of Reverse logistics & EN1 \\
\hline B8 & & & Market competition and uncertainty & EN2 \\
\hline B9 & & & $\begin{array}{l}\text { Complexity in measuring and monitoring the } \\
\text { environmental practice of suppliers }\end{array}$ & EN3 \\
\hline B10 & & & Weak environment regulatory & EN4 \\
\hline B11 & & & Lack of buying firms environmental mission & EN5 \\
\hline B12 & \multirow{6}{*}{\multicolumn{2}{|c|}{ Societal }} & Absence of government support and policies & SC1 \\
\hline B13 & & & Lack of corporate social responsibility & SC2 \\
\hline B14 & & & Insufficient society pressure & SC3 \\
\hline B15 & & & Poor customer awareness \& demand & SC4 \\
\hline B16 & & & Demand for a lower price & SC5 \\
\hline B17 & & & Lack of employee motivation & SC6 \\
\hline B18 & \multirow{7}{*}{$\begin{array}{l}\text { Knowledge } \\
\text { Technology }\end{array}$} & \multirow{7}{*}{$\&$} & Disbelief about environmental benefits & KT1 \\
\hline B19 & & & Lack of eco-literacy among supply chain stakeholders & KT2 \\
\hline B20 & & & Ineffective supplier selection strategies & KT3 \\
\hline B21 & & & The ineffective performance measurement system & KT4 \\
\hline B22 & & & lack of information technology & KT5 \\
\hline B23 & & & Lack of adoption of new technology and processes & KT6 \\
\hline B24 & & & Lack of cooperation with research institutes & KT7 \\
\hline B25 & \multirow{6}{*}{$\begin{array}{l}\text { Management } \\
\text { Stakeholders }\end{array}$} & \multirow{6}{*}{$\&$} & Manufacturer's reluctance to change & MS1 \\
\hline B26 & & & Lack of top management commitment & MS2 \\
\hline B27 & & & Lack of stakeholders involvement & MS3 \\
\hline B28 & & & Lack of supply chain integration & MS4 \\
\hline B29 & & & Lack of effective interdepartmental communication & MS5 \\
\hline B30 & & & Non-consideration of human factors & MS6 \\
\hline
\end{tabular}

\section{Research methodology flowchart}

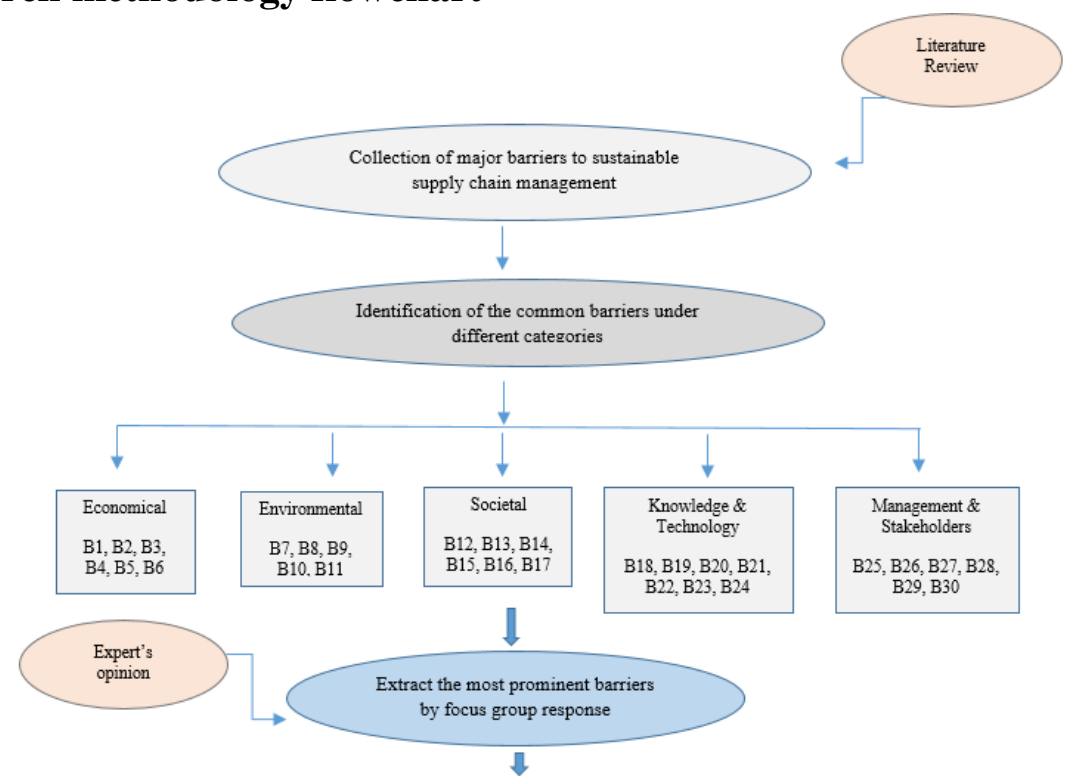




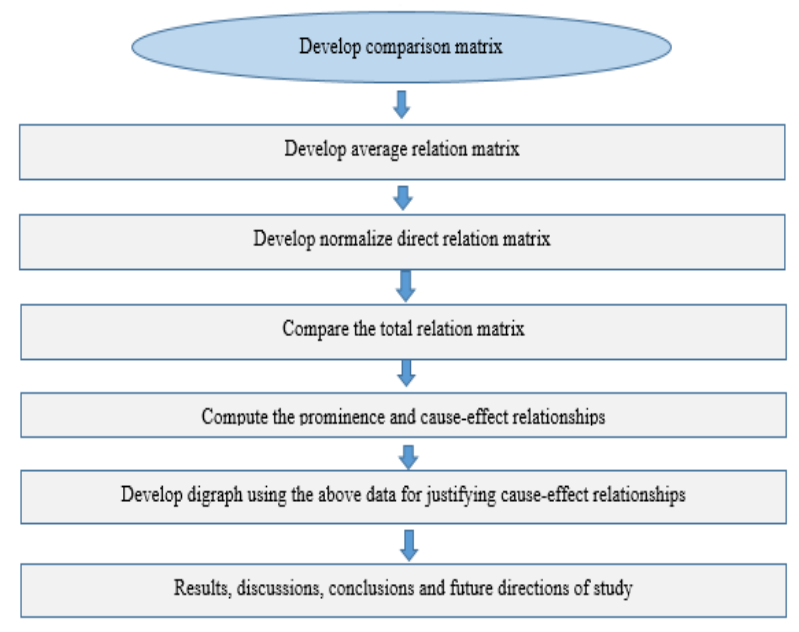

Fig 1. Process flowchart of research methodology

Firstly, a list of thirty barriers to sustainable supply chain management in the manufacturing field was enlisted by an extensive literature review. Secondly, collected barriers were grouped into five categories: economic, environmental, societal, management and stakeholder, and knowledge and technology that cover all aspects of sustainability. Applying thirty barriers to DEMATEL will be challenging to handle. So, the authors felt the urgency to narrow down the list of barriers. Thirdly, a group of experts in the apparel sector was formed, including academic, buying-house, and industry people. Fourthly, a questionnaire was designed and asked for a response from experts in a Likert scale range of $1-5$ (where $5=$ most prominent and $1=$ least prominent). Finally, upon analyzing the experts' response, twelve barriers were excluded, and eighten barriers were ready for the DEMATEL approach.

\section{DEMATEL approach}

The DEMATEL technique has gained popularity in recent decades, is a multi-criteria decision-making (MCDM) tool, usually used to analyze the interdependence of variables (R. J. Lin, 2013). In DEMATEL, variables are divided in cause and effect group to identify their causal relationship (Awasthi et al., 2014). This method has been applied in different fields previously, for example, manufacturing in Iran (Jalalifar et al., 2013), food packaging (Wang et al., 2016) and manufacturing (Gandhi et al., 2015) in India, the automobile industry in China (Xia et al., 2015) and leather industry in Bangladesh (Moktadir et al., 2018). DEMATEL ease the way of assigning value to influential factors (C. J. Lin \& Wu, 2008). Another reason to choose DEMATEL over ISM and AHP is to uncover relationships among variables based on the severity of the effect on each other (Gandhi et al., 2015). It permits the transformation of qualitative research design into quantitative 
analysis. Moreover, the application of DEMATEL in various domains has been fruitful (Wang et al., 2016). Therefore, it is apparent that the DEMATEL approach is practical for complex situations, and that is why it is selected for this study.

\section{Step 1 (Direct Relation Matrix)}

In this stage, respondents are requested to provide the degree of influence of one element on the other based on the DEMATEL scale. If there are p variables in a study, then $p \times p$ the matrix will form and the level of influence $a_{i}$ on $a_{j}$ denoted as $a_{i j}$.

Table 3. DEMATEL scale

\begin{tabular}{|c|c|}
\hline Variable & Scale \\
\hline No influence & 0 \\
\hline Very low influence & 1 \\
\hline Low influence & 2 \\
\hline High influence & 3 \\
\hline Very high influence & 4 \\
\hline$\left|\begin{array}{lll}a_{11} & a_{1 j} & a_{1 n} \\
a_{i 1} & a_{i j} & a_{i n} \\
a_{n i} & a_{n j} & a_{n n}\end{array}\right|$
\end{tabular}
feedback.

The $p \times p$ average matrix $\mathrm{Z}$ is the average of the respondents'

$$
Z=\left|\begin{array}{ccc}
0 & Z_{1 j} & Z_{1 n} \\
Z_{i 1} & Z_{i j} & Z_{\text {in }} \\
Z_{n 1} & Z_{n j} & 0
\end{array}\right|
$$

\section{Step 2 (Normalised Direct Relation Matrix)}

Normalized direct relation matrix $X$ is obtained by dividing the direct relation matrix $Z$ by $S$ where, $S=\max \left(\sum_{j=1}^{n} Z i j, \sum_{i=1}^{n} Z i j\right), X=Z / S$ and $X=\left[x_{\mathrm{ij}}\right]_{\mathrm{nxn}} \quad$ where $0 \leq x_{\mathrm{ij}} \leq 1$ 


\section{Step 3 (Total Relation Matrix)}

The total relation matrix $T$ provides both direct and indirect influence of variables instead of only indicating direct relations as of normalized direct matrix. Following equation of $T$ :

Where $I$ is the identity matrix

$$
T=X(I-X)^{-1}
$$

\section{Step 4 (Net cause-effect Values)}

Let $\mathrm{R}_{\mathrm{i}}$ denotes the sum of the $i$ th row, and $\mathrm{C}_{\mathrm{j}}$ denotes the sum of the $j$ th column in the total relation matrix $T$, where, $i=j=k=1,2,3,4 \ldots \ldots n$. Moreover, $\left(\mathrm{R}_{\mathrm{i}}+\mathrm{C}_{\mathrm{j}}\right)$ represents a degree of influence of the variables, known as prominence value. Variable with higher the prominence value, more it can affect or be affected by other variables. The value of $\left(\mathrm{R}_{\mathrm{i}}-\mathrm{C}_{\mathrm{j}}\right)$ reflects the total effect it can provide to the problem. If $\left(\mathrm{R}_{\mathrm{i}}-\mathrm{C}_{\mathrm{j}}\right)$ is positive, then variables are classified as cause group. If $\left(\mathrm{R}_{\mathrm{i}}-\mathrm{C}_{\mathrm{j}}\right)$ is negative, then variables are classified as effect groups.

\section{Step 5 (Threshold Value)}

A threshold value $\partial$ is fixed to separate variables from the total relation matrix $T$, which have negligible effects. It is necessary to choose $(\partial)$ value wisely. A higher $(\partial)$ value may miss some essential variables, while a lower (2) value may invite some insignificant variables in the problem.

\section{Results and Analysis}

Table 4. Average Direct Relation Matrix

\begin{tabular}{|c|c|c|c|c|c|c|c|c|c|c|c|c|c|c|c|c|c|c|}
\hline & C1 & $\mathrm{C} 2$ & C3 & N1 & N2 & EN3 & EN5 & SC1 & SC3 & SC5 & SC6 & KT2 & KT5 & KT6 & KT7 & MS2 & MS3 & MIS \\
\hline & & & & & & 714 & & & & & & & & & & & & \\
\hline & & & & & & & & & & & & & & & & & & \\
\hline & & & & & & & & & & & & & & & & & & \\
\hline & & & & & & & & & & & & & & & & & & \\
\hline & & & & & 0 & & & & & & & & & & & & & \\
\hline & & 4 & & & 000 & & 2.7 & 9 & & & & & & & & & & 3.42 \\
\hline & & & & & & & & & & & & & & & & & & \\
\hline & 000 & & & & 714 & & 3.2 & 0 & & & 0 & & & & & & & 2.00 \\
\hline & & & & & & & & & & & & & & & & & & 2.42 \\
\hline & & & & & & & & & & & & & & & & & & 3.1 \\
\hline & & & & & & & & & & & & & & & & & & 2.7 \\
\hline & & & & & & & & & & & & & & & & & & 3.4 \\
\hline & 286 & 0 & & & 0.286 & & & 0.4 & & & & & & 000 & & & & 1.7 \\
\hline & 429 & 1 & & & & & & 0.4 & & & & & & & & & & 2.4 \\
\hline & & & & & & & & & & & & & & & & & & 2.8 \\
\hline & 429 & & & & & & & & & & & & & & & & & 3.28 \\
\hline & & & & & & & & & & & & & & & & & & 2.8 \\
\hline & $0.42 J$ & $0.42 J$ & & & & 2.007 & $1 . / 14$ & 1.007 & & & $2.42 J$ & J.J/1 & & 2.007 & 0.200 & $J .42 J$ & J.14.14 & \\
\hline
\end{tabular}

Table 4 depicts the average direct relation matrix, representing responses garnered from a focus group of experts, including academia, 
industry, and buying-house. After receiving the individual respondent's initial response, the average of the responses was taken for the next step.

Table 5. Normalized Relation Matrix

\begin{tabular}{|c|c|c|c|c|c|c|c|c|c|c|c|c|c|c|c|c|c|c|}
\hline & & & & & & & & & & & & & & & & & & \\
\hline $\mathrm{C} 1$ & 00 & & & & & & & & & & & & & & & & & \\
\hline & & & & & & & & & & & & & & & & & & \\
\hline & & & & & & & & & & & & & & & & & & \\
\hline & & & & & & & & & & & & & & & & & & 06 \\
\hline & & & & & & & & & & & & & & & & & & \\
\hline & & & & & & & & & & & & & & & & & & 066 \\
\hline J5 & & & & & & & & & & & & & & & & & & \\
\hline C1 & & & & $0 \cap 6$ & & & & 000 & & & & & & & 0. & & & 035 \\
\hline 3 & & & & 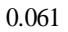 & & & 0 & & & & & & & & 041 & & & 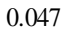 \\
\hline & & & & & & & & & & & & & & & & & & 06 \\
\hline 6 & 4 & & & 50 & & & 0.033 & 7 & & 0.0 & 000 & & & & 0.030 & & & 0.05 \\
\hline & & & & & & & & & & & & & & & & & & 066 \\
\hline & & & & 008 & & & & & & & 006 & & & & 0.050 & & & 0.03 \\
\hline & 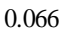 & & & & & & & & & & & & & & & & & 04 \\
\hline T7 & 577 & 2 & & .0 & & & 0.072 & & & 0.0 & $0.0 €$ & 0.069 & 0.0 & & 0.000 & & & 0.05 \\
\hline$\$ 2$ & 947 & & 0 & 0.0 & & & .052 & & & & 0.0 & & & & 0.036 & & & 0.064 \\
\hline & & & & & & & & & & & & & & & & & & 0.055 \\
\hline IS4 & 0.066 & 066 & 036 & 0.069 & 055 & .055 & 0.033 & 0.036 & .050 & 0.058 & 0.047 & 0.069 & 0.044 & 0.055 & 0.064 & 0.066 & 0.06 & 0.000 \\
\hline
\end{tabular}

Dividing each cell value by the maximum value of the sum of the rows (51.71), the normalized relation matrix (Table 5) is calculated.

Table 6. Total Relation Matrix

\begin{tabular}{llllllllllllllllll} 
EC1 & EC2 & EC3 & EN1 & EN2 & EN3 & EN5 & SC1 & SC3 & SC5 & SC6 & KT2 & KT5 & KT6 & KT7 & MS2 & MS3 & MS4 \\
\hline
\end{tabular}

\begin{tabular}{llllllllllllllllllll}
\hline EC1 & 0.215 & 0.259 & 0.181 & 0.202 & 0.175 & 0.198 & 0.217 & 0.164 & 0.174 & 0.187 & 0.179 & 0.216 & 0.156 & 0.172 & 0.230 & 0.219 & 0.269 & 0.244
\end{tabular}

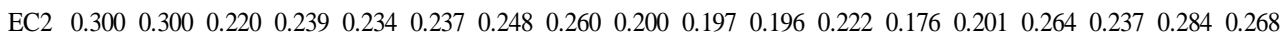

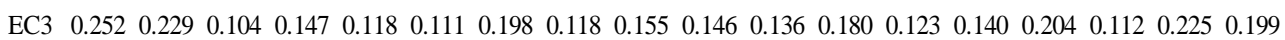

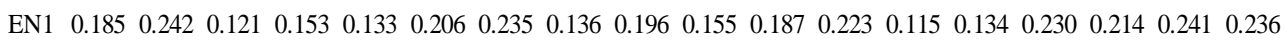

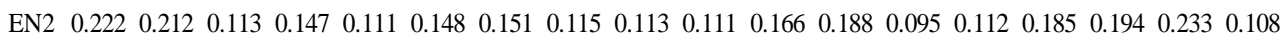
$\begin{array}{lllllllllllllllllll}\text { EN3 } & 0.238 & 0.239 & 0.151 & 0.195 & 0.127 & 0.162 & 0.226 & 0.165 & 0.198 & 0.148 & 0.206 & 0.225 & 0.133 & 0.150 & 0.223 & 0.221 & 0.250 & 0.244\end{array}$ $\begin{array}{lllllllllllllllllll}\text { EN5 } & 0.299 & 0.268 & 0.188 & 0.241 & 0.150 & 0.235 & 0.195 & 0.206 & 0.215 & 0.162 & 0.196 & 0.144 & 0.135 & 0.159 & 0.236 & 0.242 & 0.274 & 0.250\end{array}$ $\begin{array}{lllllllllllllllllll}\text { SC1 } & 0.223 & 0.218 & 0.101 & 0.133 & 0.116 & 0.190 & 0.205 & 0.101 & 0.140 & 0.109 & 0.154 & 0.190 & 0.115 & 0.137 & 0.183 & 0.163 & 0.218 & 0.187\end{array}$

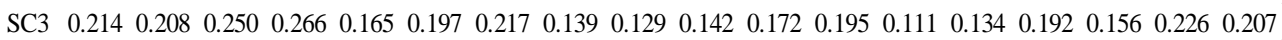

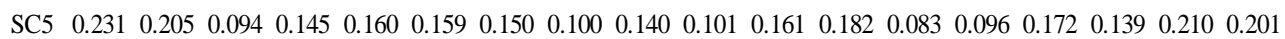
$\begin{array}{lllllllllllllllllll}\text { SC6 } & 0.221 & 0.100 & 0.103 & 0.183 & 0.169 & 0.209 & 0.185 & 0.152 & 0.178 & 0.160 & 0.131 & 0.189 & 0.098 & 0.120 & 0.182 & 0.201 & 0.229 & 0.214\end{array}$ $\begin{array}{lllllllllllllllllll}\text { KT2 } & 0.281 & 0.250 & 0.159 & 0.226 & 0.191 & 0.235 & 0.252 & 0.171 & 0.216 & 0.172 & 0.202 & 0.187 & 0.120 & 0.137 & 0.258 & 0.139 & 0.282 & 0.263\end{array}$ $\begin{array}{lllllllllllllllllll}\text { KT5 } & 0.211 & 0.194 & 0.185 & 0.120 & 0.092 & 0.125 & 0.257 & 0.099 & 0.111 & 0.088 & 0.105 & 0.130 & 0.078 & 0.163 & 0.169 & 0.127 & 0.195 & 0.162\end{array}$ $\begin{array}{lllllllllllllllllll}\text { KT6 } & 0.180 & 0.174 & 0.266 & 0.088 & 0.074 & 0.100 & 0.155 & 0.078 & 0.093 & 0.074 & 0.078 & 0.101 & 0.124 & 0.074 & 0.109 & 0.103 & 0.162 & 0.147\end{array}$

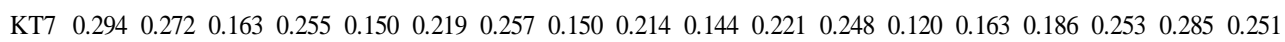

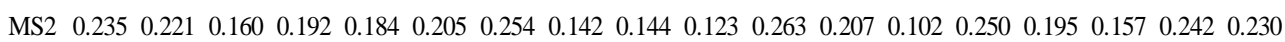

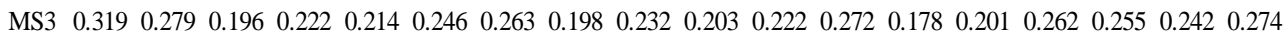
$\begin{array}{lllllllllllllllllll}\text { MS4 } & 0.298 & 0.281 & 0.286 & 0.238 & 0.197 & 0.235 & 0.234 & 0.170 & 0.211 & 0.195 & 0.209 & 0.257 & 0.158 & 0.188 & 0.257 & 0.250 & 0.286 & 0.211\end{array}$

Threshold Value $(\partial)=0.187$ 
Table 7. Sum of influence given and received on barriers

\begin{tabular}{ccccc}
\hline Barriers & $\mathrm{Ri}$ & $\mathrm{Cj}$ & $\mathrm{Ri}+\mathrm{Cj}$ & $\mathrm{Ri}-\mathrm{Cj}$ \\
\hline EC1 & 3.658 & 4.417 & 8.074 & -0.759 \\
EC2 & 4.282 & 4.152 & 8.434 & 0.130 \\
EC3 & 2.898 & 3.041 & 5.939 & -0.143 \\
EN1 & 3.342 & 3.390 & 6.731 & -0.048 \\
EN2 & 2.723 & 2.760 & 5.483 & -0.037 \\
EN3 & 3.501 & 3.417 & 6.918 & 0.084 \\
EN5 & 3.793 & 3.898 & 7.692 & -0.105 \\
SC1 & 2.883 & 2.664 & 5.547 & 0.219 \\
SC3 & 3.319 & 3.059 & 6.377 & 0.260 \\
SC5 & 2.730 & 2.617 & 5.346 & 0.113 \\
SC6 & 3.024 & 3.183 & 6.207 & -0.159 \\
KT2 & 3.742 & 3.558 & 7.300 & 0.184 \\
KT5 & 2.611 & 2.220 & 4.830 & 0.391 \\
KT6 & 2.179 & 2.730 & 4.910 & -0.551 \\
KT7 & 3.844 & 3.737 & 7.582 & 0.107 \\
MS2 & 3.507 & 3.381 & 6.888 & 0.125 \\
MS3 & 4.278 & 4.354 & 8.632 & -0.076 \\
MS4 & 4.162 & 3.896 & 8.058 & 0.265 \\
\hline
\end{tabular}

$\mathrm{R}_{\mathrm{i}}+\mathrm{C}_{\mathrm{j}}$ denotes the degree of the relative importance of barriers known as prominence value. Variables with a higher $R_{i}+C_{j}$ value, more likely to affect or be affected by other variables. The $\mathrm{R}_{\mathrm{i}}-\mathrm{C}_{\mathrm{j}}$ value represents the total effect it cast on the overall problem. The positive value of $\mathrm{R}_{\mathrm{i}}-\mathrm{C}_{\mathrm{j}}$ means it will affect others, while the negative value of $\mathrm{R}_{\mathrm{i}}-\mathrm{C}_{\mathrm{j}}$ says it will be affected by other variables.

Table 8. Degree of the relative importance of each barrier

\begin{tabular}{ccc}
\hline Rank & Barriers & $\mathrm{Ri}+\mathrm{Cj}$ \\
\hline 1 & MS3 & 8.632 \\
2 & EC2 & 8.434 \\
3 & EC1 & 8.074 \\
4 & MS4 & 8.058 \\
5 & EN5 & 7.692 \\
6 & KT7 & 7.582 \\
7 & KT2 & 7.300 \\
8 & EN3 & 6.918 \\
9 & MS2 & 6.888 \\
10 & EN1 & 6.731 \\
11 & SC3 & 6.377 \\
12 & SC6 & 6.207 \\
13 & EC3 & 5.939 \\
14 & SC1 & 5.547 \\
15 & EN2 & 5.483 \\
16 & SC5 & 5.346 \\
17 & KT6 & 4.910 \\
18 & KT5 & 4.830 \\
\hline
\end{tabular}


Table 9. Cause-effect group

\begin{tabular}{ccc}
\hline Rank & Cause group & Ri-Cj \\
\hline 1 & KT5 & 0.391 \\
2 & MS4 & 0.265 \\
3 & SC3 & 0.260 \\
4 & SC1 & 0.219 \\
5 & KT2 & 0.184 \\
6 & EC2 & 0.130 \\
7 & MS2 & 0.125 \\
8 & SC5 & 0.113 \\
9 & KT7 & 0.107 \\
10 & EN3 & 0.084 \\
\hline Rank & Effect group & Ri-Cj \\
\hline 1 & EC1 & -0.759 \\
2 & KT6 & -0.551 \\
3 & SC6 & -0.159 \\
4 & EC3 & -0.143 \\
5 & EN5 & -0.105 \\
6 & MS3 & -0.076 \\
7 & EN1 & -0.048 \\
8 & EN2 & -0.037 \\
\hline
\end{tabular}

From Table 8, according to prominence value, lack of stakeholder's involvement (MS3), High costs of sustainability adoption (EC2), Insignificant financial gains (EC1), lack of supply chain integration (MS4), Lack of buying firms environmental mission (EN5) are the top five barriers to consider. From Table 9, barriers with positive $\mathrm{R}_{\mathrm{i}}-\mathrm{C}_{\mathrm{j}}$ value are cause group, and barriers with negative $\mathrm{R}_{\mathrm{i}}-\mathrm{C}_{\mathrm{j}}$ value are effect group. Under cause group, there are ten barriers, namely, lack of information technology (KT5), Lack of government support and policies (MS4), Insufficient society pressure (SC3), Lack of supply chain integration (SC1), Insignificant financial gains (KT2), Lack of eco-literacy among supply chain stakeholders (EC2), Lack of top management commitment (MS2), Complexity in measuring and monitoring the environmental practice of suppliers (SC5), demand for a lower price (KT7), Lack of cooperation with research institutes (EN3). Among the cause group, Lack of information technology (KT5), Lack of government support and policies (MS4), Insufficient society pressure (SC3) ranked highest.

Under effect group, there are eight barriers which are, High costs of sustainability adoption (EC1), lack of resource and capability (KT6), Lack of Reverse logistics (SC6), Market competition and uncertainty (EC3), Lack of buying firms environmental mission (EN5), Lack of employee motivation (MS3), Lack of adoption of new technology and processes (EN1), Lack of stakeholders involvement (EN2). Among the effect group, High costs of sustainability adoption (EC1), lack of resource and capability (KT6), Lack of Reverse logistics (SC6) ranked as the top three. 


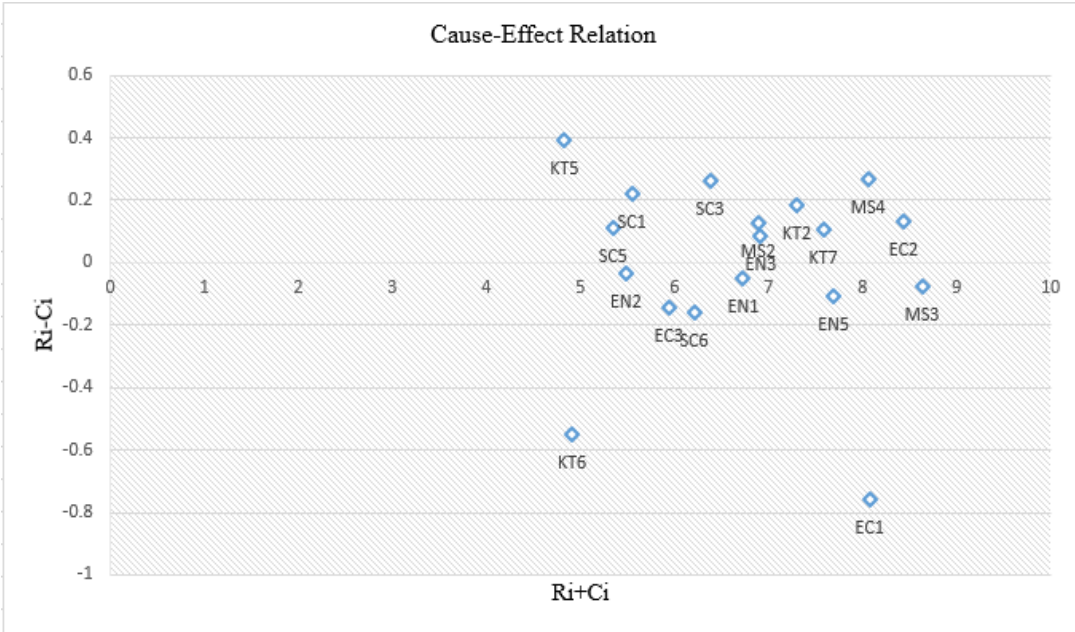

Fig 2. Causal Diagram

From the causal diagram, KT5, MS4, and SC3 are the critical barriers for SSCM adoption in the T\&A sector of Bangladesh. According to relative importance, MS3, EC2, and EC1 are the top three barriers among eighteen barriers.

\section{Discussion}

Research outcome shows ten cause barriers and eight effect barriers. In this section, the authors tried to delineate how each of the cause barriers stirs each effect barrier. The authors proposed corrective action to address each cause barriers, which consequently mitigate the effect barriers.

Lack of information technology can result in a lack of adoption of new technology and processes. The scarcity of information technology and experts in this particular area hinders the adoption of new technology and operations. The textile and apparel industry should adapt itself with relevant information technology and prepare experts to smooth the latest technology transfer, installation, and adaptation to address this challenge.

Absence of government support and policies trigger the high cost of sustainability adoption. Without government financial support and sustainability-friendly policies, the textile and apparel sector cannot make any significant footsteps in their way to achieving sustainability in supply chain management. To address this issue, the government should offer financial incentives to the textile and apparel industry and construct a set of guidelines that will be easy to integrate.

Lack of insufficient society pressure for sustainable products influences the absence of reverse logistics. It is the society (customers, consumers) from where the demand for sustainability (through sustainable products) should come forward in the first place. Upon massive pull for 
sustainable products, manufacturers will integrate reverse logistics in their supply chain. To address this barrier, dissemination of sustainability concepts and advantageous facets of sustainability can be handy.

Lack of supply chain integration engenders the effects of reverse logistics, market competition, and uncertainty. Forward and backward integration is a prerequisite for supply chain management to keep reverse logistics functional. The textile and apparel sector should extend its supply chain on the supplier's side and customer's side to reuse, remake, and recycle textile and apparel products.

Insignificant financial gains breed the effects of lack of resources and capability and lack of employee motivation. Predisposed concept of less economic turn out from sustainability endeavour deters organization from acquiring new resource and uplift caliber. High investment but less turn out, which is true partly initially, sway the industry from sustainability. In the end, financial gains outnumbered the initial cost. The textile and apparel sector should be well informed about the societal, environmental benefits, and economic outcome, which may change the organization's perception and facilitate new resource acquisition and capability enhancement.

Lack of eco-literacy causes a downfall of stakeholder involvement. Stakeholders in the textile and apparel supply chain feel uninterested in complying with the sustainability approach without convincing financial gain and tangible benefits. Extensive training and seminar program about sustainable supply chain management can be a potent tactic to educate the stakeholders. Eco-literacy programs can engender the urge among stakeholders to participate in the sustainability movement for economic, societal, and environmental gain and confirm the generations' wellbeing.

The lack of top management's commitment is reflected in the absence of resources, capability, and stakeholder involvement. It is the top management of the organization who beholds the power of decision-making. The mission and vision of organizations reflect top management's strategic planning and level of thinking. To address this barrier, top management from all the textile and apparel supply chain firms should come forward simultaneously and comply with sustainability initiatives. Top management should evince their commitment through active participation to ease new resource acquisition and confirm stakeholder's involvement.

Difficulty in measuring and regulating environmental practices resulted in lack of buying house's environmental mission. Buying firms can be the harbinger of sustainability adoption in the textile and apparel supply chain. To some extent, buying firms can create pressure on manufacturers. Measuring and monitoring suppliers' environmental practices in the tortuous textile and apparel supply chain has never been easy to resist buying firms from fulfilling their environmental mission. It is essential to install a flexible 
method to measure and monitor all the participatory firms' environmental practices in the textile and apparel supply chain, which may increase firms' accountability for their practices. Demand for lower prices instigates market competition and uncertainty. One of the fundamental barriers to sustainability is the demand for lower prices from the consumer end. To satiate customers with cheap products, manufacturers act crazy and unsettled the whole market. Manufacturers often show no mercy to the environment to stay competitive and gain a small profit margin. Consumers have to be willing to pay a little extra for sustainable products. Consumers' commitment to sustainable goods can positively drive the textile and apparel supply chain.

\section{Conclusion}

This study explores the challenges to sustainable supply chain management in Bangladesh's textile and apparel sector with the DEMATEL technique. At the first stage of this study, challenges to sustainable supply chain management in the manufacturing, automobile, leather, and textile industry in India, China, Bangladesh, and other south Asian countries are collected through extensive literature review. Secondly, collected barriers are categorized into economic, environmental, societal, knowledge and technology, management, and stakeholder groups. Thirdly, opinion from expert focus groups is taken into account to justify the barriers and narrow down the list of barriers to ensure the most influential ones. Finally, the collection of data and analysis are completed using the DEMATEL approach.

This study is the first of its kind, in the textile and apparel sector of Bangladesh. Previous research explores sustainability adoption in supply chain management, sticking to the limited subset of sustainability concepts and dealing with environmental concerns only. Aggregation of sustainability subset: knowledge and technology, management, and stakeholder's commitment strengthen this study's outcome. Moreover, this study unravels the cause-effect relationship between the barriers and proposed corrective action to address the cause of barriers.

There are a few limitations in this study, which set the direction for future works. There is a scope to identify and collect more barriers from the extensive literature review. It is possible to include more categories of barriers to make the research work more comprehensive. Response for the DEMATEL matrix can be increased. This study can be stretched to a similar field in other countries. Different MCDM tools like ISM, AHP, and TOPSIS can be deployed to see the research outcome's difference. 


\section{References:}

1. Awasthi, A., Grzybowska, K., Awasthi, A., \& Grzybowska, K. (2014). Barriers of the Supply Chain Integration. Springer, 15-30. https://doi.org/10.1007/978-3-319-07287-6_2

2. Bank, B. (n.d.). Quarterly Review on RMG: April-June FY'20 1.

3. Bansal, P., \& Roth, K. (2000). Why Companies Go Green: A Model of Ecological Responsiveness. Academy of Management Journal, 43(4), 717-736. https://doi.org/10.5465/1556363

4. Carter, C. R., \& Liane Easton, P. (2011). Sustainable supply chain management: Evolution and future directions. International Journal of Physical Distribution \& Logistics Management, 41(1), 46-62. https://doi.org/https://doi.org/10.1108/09600031111101420

5. Carter, Craig R., \& Easton, P. L. (2011). Sustainable supply chain management: Evolution and future directions. In International Journal of Physical Distribution and Logistics Management (Vol. 41, Issue 1, pp. 46-62). Emerald Group Publishing Limited. https://doi.org/10.1108/09600031111101420

6. Ciliberti, F., Pontrandolfo, P., \& Scozzi, B. (2008). Investigating corporate social responsibility in supply chains: an SME perspective. Journal of Cleaner Production, 16(15), 1579-1588. https://doi.org/10.1016/j.jclepro.2008.04.016

7. Coronavirus: Bangladesh's garment industry risks collapse | Asia| An in-depth look at news from across the continent | DW | 25.03.2020. (n.d.). Retrieved January 13, 2021, from https://www.dw.com/en/coronavirus-bangladeshs-garment-industryrisks-collapse/a-52917410

8. Diabat, A., \& Govindan, K. (2011). An analysis of the drivers affecting the implementation of green supply chain management. Resources, Conservation and Recycling, 55(6), 659-667. https://doi.org/10.1016/j.resconrec.2010.12.002

9. EM, P., \& C., V. der L. (1995). Green and competitive: ending the stalemate. Harvard Business Review, 73(5), 120-134.

10. Font, X., Tapper, R., Schwartz, K., \& Kornilaki, M. (2008). Sustainable supply chain management in tourism. Business Strategy and the Environment, 17(4), 260-271. https://doi.org/10.1002/bse.527

11. Gandhi, S., Mangla, S. K., Kumar, P., \& Kumar, D. (2015). "Evaluating Factors in Implementation of Successful Green Supply Chain Management Using DEMATEL: A Case Study.” International Strategic Management Review, 3(1-2), 96-109.

12. Gardas, B. B., Raut, R. D., \& Narkhede, B. (2018). Modeling the challenges to sustainability in the textile and apparel (T\&A) sector: A 
Delphi-DEMATEL approach. Sustainable Production and Consumption, 15, 96-108. https://doi.org/10.1016/j.spc.2018.05.001

13. Govindan, K., Diabat, A., \& Shankar, K. M. (2015). Analyzing the Drivers of Green Manufacturing with Fuzzy Approach. Journal of Cleaner Production, 96, 182-193.

14. Govindan, Kannan, Kaliyan, M., Kannan, D., \& Haq, A. N. (2014). Barriers analysis for green supply chain management implementation in Indian industries using analytic hierarchy process. International Journal of Production Economics, 147(PART B), 555-568. https://doi.org/10.1016/j.ijpe.2013.08.018

15. Harland, C. M. (1996). Supply chain management: Relationships, chains, and networks. British Journal of Management, 7(SPEC. ISS.). https://doi.org/10.1111/j.1467-8551.1996.tb00148.x

16. Hassini, E., Surti, C., \& Searcy, C. (2012). A literature review and a case study of sustainable supply chains with a focus on metrics. International Journal of Production Economics, 140(1), 69-82. https://doi.org/10.1016/j.ijpe.2012.01.042

17. Islam, M. H., Sarker, M. R., Hossain, M. I., Ali, K., \& Noor, K. M. A. (2020). Towards Sustainable Supply Chain Management (SSCM): A Case of Leather Industry. Journal of Operations and Strategic Planning,2516600X2092431.

https://doi.org/10.1177/2516600x20924313

18. Jalalifar, S., Hafshejani, K. F., \& Movahedi., M. (2013). Evaluation of the Effective Barriers in GSCM Implementation Using DEMATEL Method (Case Study: Iran Khodro CO.”). Nature and Science, 11(11), 95-102.

19. Kaur, J., Sidhu, R., Awasthi, A., Chauhan, S., \& Goyal, S. (2018). A DEMATEL based approach for investigating barriers in green supply chain management in Canadian manufacturing firms. International Journal of Production Research, 56(1-2), 312-332. https://doi.org/10.1080/00207543.2017.1395522

20. Khan, M., Hussain, M., Gunasekaran, A., Ajmal, M. M., \& Helo, P. T. (2018). Motivators of social sustainability in healthcare supply chains in the UAE-Stakeholder perspective. Sustainable Production and Consumption, 14, 95-104. https://doi.org/10.1016/j.spc.2018.01.006

21. Koberg, E., \& Longoni, A. (2019). A systematic review of sustainable supply chain management in global supply chains. Journal of Cleaner Production, 207, 1084-1098. https://doi.org/10.1016/j.jclepro.2018.10.033

22. Lin, R. J. (2013). Using fuzzy DEMATEL to evaluate the green supply chain management practices. Journal of Cleaner Production, 40, 3239. https://doi.org/10.1016/j.jclepro.2011.06.010 
23. Lintukangas, K., Kähkönen, A. K., \& Ritala, P. (2016). Supply risks as drivers of green supply management adoption. Journal of Cleaner Production, 112 ,

1901-1909. https://doi.org/10.1016/j.jclepro.2014.10.089

24. Lorek, S., \& Spangenberg, J. H. (2014). Sustainable consumption within a sustainable economy - Beyond green growth and green economies. Journal of Cleaner Production, 63, 33-44. https://doi.org/10.1016/j.jclepro.2013.08.045

25. Luthra, S., Kumar, V., Kumar, S., \& Haleem, A. (2011). Barriers to implement green supply chain management in automobile industry using interpretive structural modeling technique-an Indian perspective. Journal of Industrial Engineering and Management, 4(2), 231-257. https://doi.org/10.3926/jiem.2011.v4n2.p231-257

26. Luthra, S., Mangla, S. K., Xu, L., \& Diabat, A. (2016). Using AHP to evaluate barriers in adopting sustainable consumption and production initiatives in a supply chain. International Journal of Production Economics, 181, 342-349. https://doi.org/10.1016/j.ijpe.2016.04.001

27. Majumdar, A., \& Sinha, S. K. (2019). Analyzing the barriers of green textile supply chain management in Southeast Asia using interpretive structural modeling. Sustainable Production and Consumption, 17, 176-187. https://doi.org/10.1016/j.spc.2018.10.005

28. Marshall, D., McCarthy, L., McGrath, P., \& Claudy, M. (2015). Going above and beyond: How sustainability culture and entrepreneurial orientation drive social sustainability supply chain practice adoption. Supply Chain Management, 20(4), 434-454. https://doi.org/10.1108/SCM-08-2014-0267

29. Mathiyazhagan, K., Govindan, K., NoorulHaq, A., \& Geng, Y. (2013). An ISM approach for the barrier analysis in implementing green supply chain management. Journal of Cleaner Production, 47, 283297. https://doi.org/10.1016/j.jclepro.2012.10.042

30. Moktadir, M. A., Ali, S. M., Rajesh, R., \& Paul, S. K. (2018). Modeling the interrelationships among barriers to sustainable supply chain management in the leather industry. Journal of Cleaner Production, 181 ,

631-651. https://doi.org/10.1016/j.jclepro.2018.01.245

31. Mont, O., Neuvonen, A., \& Lähteenoja, S. (2014). Sustainable lifestyles 2050: Stakeholder visions, emerging practices, and future research. Journal of Cleaner Production, 63, 24-32. https://doi.org/10.1016/j.jclepro.2013.09.007

32. Muduli, K., Govindan, K., Barve, A., \& Geng, Y. (2013). Barriers to green supply chain management in Indian mining industries: A graph- 
theoretic approach. Journal of Cleaner Production, 47, 335-344. https://doi.org/10.1016/j.jclepro.2012.10.030

33. Pomponi, F., Moghayedi, A., Alshawawreh, L., D’Amico, B., \& Windapo, A. (2019). Sustainability of post-disaster and post-conflict sheltering in Africa: What matters? Sustainable Production and Consumption, 20, 140-150. https://doi.org/10.1016/j.spc.2019.06.007

34. Prakash, C., \& Barua, M. K. (2015). Integration of AHP-TOPSIS method for prioritizing the solutions of reverse logistics adoption to overcome its barriers under fuzzy environment. Journal of Manufacturing Systems, 37, 599-615. https://doi.org/10.1016/j.jmsy.2015.03.001

35. Rajeev, A., Pati, R. K., Padhi, S. S., \& Govindan, K. (2017). Evolution of sustainability in supply chain management: A literature review. Journal of Cleaner Production, 162, 299-314. https://doi.org/10.1016/j.jclepro.2017.05.026

36. RMG industry as the major employment sector | The Daily Star. (n.d.). Retrieved January 13, 2021, from https://www.thedailystar.net/supplements/28th-anniversarysupplements/entrepreneurship-key-youth-employment/news/rmgindustry-the-major-employment-sector-1702951

37. Sajjad, A., Eweje, G., \& Tappin, D. (2015). Sustainable Supply Chain Management: Motivators and Barriers. Business Strategy and the Environment, 24(7), 643-655. https://doi.org/10.1002/bse.1898

38. Sarker, M. R., Ahmed, F., Deb, A. K., \& Chowdhury, M. (2018). Identifying barriers for implementing Green Supply Chain Management (Gscm) In footwear industry of Bangladesh: A Delphi study approach. Leather and Footwear Journal, 18(3), 175-186. https://doi.org/10.24264/lfj.18.3.1

39. Schönborn, G., Berlin, C., Pinzone, M., Hanisch, C., Georgoulias, K., \& Lanz, M. (2019). Why social sustainability counts: The impact of corporate social sustainability culture on financial success. Sustainable Production and Consumption, 17, 1-10. https://doi.org/10.1016/j.spc.2018.08.008

40. Seuring, S., \& Müller, M. (2008). From a literature review to a conceptual framework for the sustainable supply chain management. Journal of Cleaner Production, 16(15), 1699-1710. https://doi.org/10.1016/j.jclepro.2008.04.020

41. Silvestre, B. S., Monteiro, M. S., Viana, F. L. E., \& de Sousa-Filho, J. M. (2018). Challenges for sustainable supply chain management: When stakeholder collaboration becomes conducive to corruption. Journal of Cleaner Production, 194, 766-776. https://doi.org/10.1016/j.jclepro.2018.05.127 
42. Slawinski, N., \& Bansal, P. (2011). MANAGING THE TIME PARADOX IN BUSINESS SUSTAINABILITY. Academy of Management Proceedings, 2011(1), 1-6. https://doi.org/10.5465/ambpp.2011.65870485

43. Svensson, G., \& Wagner, B. (2015). Implementing and managing economic, social, and environmental efforts of business sustainability propositions for measurement and structural models. Management of Environmental Quality: An International Journal. https://doi.org/doi.org/10.1108/MEQ-09-2013-0099

44. Taghikhah, F., Voinov, A., \& Shukla, N. (2019). Extending the supply chain to address sustainability. In Journal of Cleaner Production (Vol. 229, pp.652-666). Elsevier https://doi.org/10.1016/j.jclepro.2019.05.051

45. Tseng, M. L., Islam, M. S., Karia, N., Fauzi, F. A., \& Afrin, S. (2019). A literature review on green supply chain management: Trends and future challenges. In Resources, Conservation and Recycling (Vol. 141, pp. 145-162). Elsevier B.V. https://doi.org/10.1016/j.resconrec.2018.10.009

46. Walker, H., Sisto, L. Di, \& McBain, D. (2008). "Drivers and Barriers to Environmental Supply Chain Management Practices: Lessons from the Public and Private Sectors.” Journal of Purchasing and Supply Management, 14(1), 69-85.

47. Wang, Z., Mathiyazhagan, K., Xu, L., \& Diabat, A. (2016). A decision-making trial and evaluation laboratory approach to analyze the barriers to Green Supply Chain Management adoption in a food packaging company. Journal of Cleaner Production, 117, 19-28. https://doi.org/10.1016/j.jclepro.2015.09.142

48. Xia, X., Govindan, K., \& Zhu, Q. (2015). Analyzing Internal Barriers for Automotive Parts Remanufacturers in China Using GreyDEMATEL Approach. Journal of Cleaner Production, 87, 811825.

49. Zhu, Qinghua, \& Geng, Y. (2013). Drivers and barriers of extended supply chain practices for energy saving and emission reduction among Chinese manufacturers. Journal of Cleaner Production, 40, 612. https://doi.org/10.1016/j.jclepro.2010.09.017 